\title{
Demonstration of Phytochemicals and In-vitro Antioxidant and Anti-inflammatory activity by methanolic extract of Elettaria

\author{
cardamomum
}

Tanwy Chowdhury ${ }^{1}$ and Md. Shahidul Islam ${ }^{2}$

${ }_{1,2}$ Department of Pharmacy, University of Science and Technology Chittagong, Chattogram, Bangladesh.

*Corresponding Author: Md. Shahidul Islam, Assistant Professor, Department of Pharmacy, University of Science \& Technology Chittagong (USTC), Bangladesh.

Received date: November 25, 2020; Accepted date: December 01, 2020; Published date: December 07, 2020

Citation: Chowdhury T. and Md. S. Islam (2020) Demonstration of Phytochemicals and In-vitro Antioxidant and Anti-inflammatory activity by methanolic extract of Elettaria cardamomum, J. Pharmaceutics and Pharmacology Research 3(3); DOI:10.31579/2693-7247/023

Copyright: (C) 2020, Shahidul Islam, This is an open access article distributed under the Creative Commons Attribution License, which permits unrestricted use, distribution, and reproduction in any medium, provided the original work is properly cited.

\begin{abstract}
The existing research study attempts to untie novel avenues for development of the medicinal exercises of Elettaria cardamomum, fashionable known as the "Queen of Spices" and locally recognized as "elaichi". Its seeds are utilized as abortifacient, acrid, alexiteric, aromatic, sweet, cardiac tonic, cooling, carminative, digestive, diuretic, expectorant, stimulant and also tonic beneficial in the asthma, haemorrhoids, bronchitis, strangury, renal in addition to vesical calculi, anorexia, halitosis, gastropathy dyspepsia as well as burning sensation. The prime goal of this research work is to evaluate antioxidant as well as anti-inflammatory properties of the traditional Bangladeshi medicinal extracts in addition to examine these activities. The aim in present work was to screen the phytochemical profile as well as pharmacological activities of the methanolic extract of this plant's leaves. To explore pharmacological actions DPPH scavenging test and the HRBC membrane stabilization techniques were done for the antioxidant and also anti-inflammatory test respectively. The pharmacological works revealed that plant extracts might have noteworthy antioxidant effect which is possibly mediated by the inhibition of DPPH free radical which is accountable for oxidation. The IC50 values by the DPPH scavenging test observed for the standard and the leaves were $106.38 \mu \mathrm{g} / \mathrm{ml} \& 594.47 \mu \mathrm{g} / \mathrm{ml}$ respectively. There is also moderate anti-inflammatory activity. The $\mathrm{IC}_{50}$ values for anti-inflammatory activity by standard \& leaves were $35.04 \mu \mathrm{g} / \mathrm{ml}$ and $944.0 \mu \mathrm{g} / \mathrm{ml}$ respectively.
\end{abstract}

Keywords: antioxidant, anti-inflammatory, elettaria cardamomum, $\mathrm{IC}_{50}$ values

\section{Introduction}

The three main important necessities of life are food, clothing and also shelter. A host of additional useful manufactured goods are supplied to him by plant kingdom [1]. The nature has offered a complete store-house of the remedies to cure all the ailments of mankind. The knowledge of the drugs has collected over the thousands of years as a result of the man's curious nature so that nowadays it possess many effectual means of ensuring the health-care [2]. The cardamom oil is effectual as an antioxidant and also can increase intensities of glutathione which is a natural antioxidant in our body. The cause is increased by the increasing content of oil from the 100 to $5000 \mathrm{ppm}$ [3]. The plants that acquire therapeutic properties and exert beneficial the pharmacological effects on animal body are by and large designated as the "Medicinal Plants" [4]. Even though there are no noticeable morphological characteristics in medicinal plants producing with them, up till now they acquire some out of the ordinary qualities and virtues that construct them medicinally imperative [5]. The plants which naturally synthesis and also accumulate several secondary metabolites like alkaloids, volatile oils, glycosides, tannins and also contain minerals in addition to vitamins possess the medicinal properties [6]. So from the extremely beginning of civilization, natives have depended on the nature for their essential needs, for the making of the flavors, diet, housing, nourishments, wear and also drugs
[7]. That's why many medicinal plants have made source of the refined traditional treatment systems that have been in being for the thousands of years and also remain to distribute human with innovative medications [8].

\section{Materials and Methods:}

\section{Plant material}

For this research works, the leaves of Elettaria cardamomum was accumulated during June, 2019 from the University campus of University of Chittagong, Bangladesh.

\section{Determination of Total Phenolic Content (TPC)}

As it is known that in the alkaline condition phenols ionize absolutely. WhileFolin-Ciocalteu's reagent is used in this ionized phenolic solution, the reagent will freely oxidize the phenols. Usual color of FolinCiocalteu's reagent is yellow and after the oxidation process the solution converts blue. The strength of the color alteration is restrained in a spectrophotometer at $760 \mathrm{~nm}$. The absorbance value will imitate the total phenolic content of the compound [9].

\section{Method of sample preparation}

In this research work, the total phenolics of the extracts were evaluated using the Folin and Ciocalteu reagent, following the method designated with slight alterations [12]. The test sample $(0.2 \mathrm{~mL})$ was variegated with 
$0.6 \mathrm{~mL}$ of water and $0.2 \mathrm{~mL}$ of Folin-Ciocalteu's phenol reagent (1: 1). Subsequently, $5 \mathrm{~min}, 1 \mathrm{~mL}$ of saturated sodium carbonate solution $(8 \% \mathrm{w} / \mathrm{v}$ in water) was added to the mixture and the volume was completed up to $3 \mathrm{~mL}$ with distilled water. Then the reaction was preserved in the dark for 30min and after centrifuging the absorbance of blue color from dissimilar samples was restrained at $760 \mathrm{~nm}$. All determinations were carried out in triplicate [10].

\section{Method of sample preparation}

In this research work, fifty micro liters $(\mu 1)$ of tannins extract for each sample was occupied in test tube and volume was completed to $1.0 \mathrm{ml}$ with distilled water. Then, $0.5 \mathrm{ml}$ Folin Ciocalteu reagent was added and varied accurately. Then $2.5 \mathrm{ml} 20$ per cent sodium carbonate solution was added and varied accurately and kept for 40 minutes at room temperature. Moreover, the optical density was reserved at $725 \mathrm{~nm}$ in UV spectrophotometer and concentration was assessed [11].

\section{Results and Discussion}

\section{Phytochemical screening:}

In Table 3, it is shown that different chemical constituents such as alkaloids, flavonoids, glycosides, phenols, saponins, tannins, terpenoids and triterpenes was present in a Acalyphahispida. And are clearly accountable for its different therapeutic and pharmacological actions.

\begin{tabular}{|c|c|c|c|c|}
\hline Test sample & Absorbance & TPC (mg of GAE/g) & Average & TPC (mg of GAE/g) \pm SEM \\
\hline & 0.405 & 37.32 & & \\
\hline Leaves & 0.413 & 36.48 & 36.74 & $36.74 \pm 0.5$ \\
\hline & 0.411 & 36.44 & & \\
\hline
\end{tabular}

Table 1: Total phenolic content (TPC) of Elettaria cardamomum

Total phenolic content (TPC) observed for leaves of Elettaria cardamomum was $36.74 \pm 0.5 \mathrm{mg}$ of GAE/g.

\begin{tabular}{|c|c|c|c|c|}
\hline Test sample & Absorbance & TTC (mg of TAE/g) & Average & TTC (mg of TAE/g) \pm SEM \\
\hline & 0.402 & 2.771 & & \\
\hline Leaves & 0.330 & 2.803 & 2.788 & $2.788 \pm 0.017$ \\
\hline & 0.398 & 2.787 & & \\
\hline
\end{tabular}

Table 2: Total tannin content (TTC)

Total tannin content (TTC) observed for leaf of Elettaria cardamomum was $2.788 \pm 0.017 \mathrm{mg}$ of TAE/g.

\begin{tabular}{|l|l|l|}
\hline Secondary metabolites & Name of the test & Results \\
\hline Glycosides & General test & +++ \\
\hline Flavonoids & Specific test & +++ \\
\hline Alkaloids & Wagner test & ++ \\
\hline Phenols & Litmus test & +++ \\
\hline Saponins & Froth test & +++ \\
\hline Tannins & Ferric chloride test & ++ \\
\hline Terpenoids & General test & +++ \\
\hline Triterpenes & Salkowski's test & ++ \\
\hline
\end{tabular}

Table 3: Different chemical compositions resent in plants

\section{Anti-inflammatory Activity}

Percent inhibition of protein denaturation was calculated as follows [11]:

$$
\% \text { inhibition }=\frac{\text { Control }- \text { Sample }}{\text { Control })} \times 100
$$

In this research work, the method of HRBC membrane stabilization was selected to estimate anti-inflammatory activities.

\begin{tabular}{|l|l|l|}
\hline & Absorbance & Average \\
\hline & 0.468 & \\
\hline Control & 0.461 & 0.465 \\
\hline & 0.467 & \\
\hline
\end{tabular}

Table 4: Average absorbance of control

\begin{tabular}{|c|c|c|c|c|c|}
\hline Concentration $(\mu \mathrm{g} / \mathrm{ml})$ & Absorbance & \% Inhibition & Average & $\%$ Inhibition \pm SEM & IC50 $(\mu \mathrm{g} / \mathrm{ml})$ \\
\hline \multirow[t]{3}{*}{125} & 0.539 & 2.43 & \multirow[t]{3}{*}{2.41} & \multirow[t]{3}{*}{$2.41 \pm 0.8$} & \\
\hline & 0.537 & 1.81 & & & \\
\hline & 0.535 & 2.99 & & & \\
\hline \multirow[t]{3}{*}{250} & 0.501 & 20.13 & \multirow[t]{3}{*}{21.00} & \multirow[t]{3}{*}{$21.00 \pm 0.3$} & \multirow[t]{3}{*}{944.06} \\
\hline & 0.500 & 21.05 & & & \\
\hline & 0.503 & 21.81 & & & \\
\hline \multirow[t]{3}{*}{500} & 0.452 & 57.05 & \multirow{3}{*}{57.47} & \multirow[t]{3}{*}{$57.47 \pm 0.7$} & \\
\hline & 0.451 & 58.90 & & & \\
\hline & 0.452 & 56.45 & & & \\
\hline 1000 & 0.413 & 63.90 & 64.68 & $64.68 \pm 0.5$ & \\
\hline
\end{tabular}




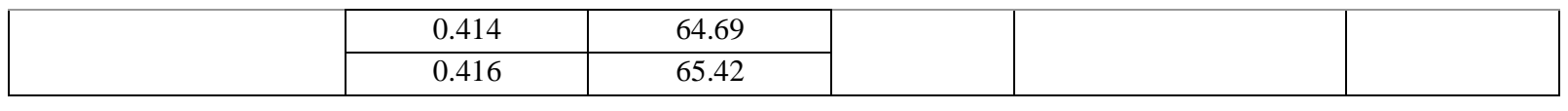

Table 5. Spectroscopic Determination of Anti-inflammatory Activity of leaves.

\begin{tabular}{|c|c|c|c|c|c|}
\hline Concentration $(\mu \mathrm{g} / \mathrm{ml})$ & Absorbance & \% Inhibition & Average & $\%$ Inhibition \pm SEM & IC50 $(\mu \mathrm{g} / \mathrm{ml})$ \\
\hline \multirow[t]{3}{*}{125} & 0.445 & 57.10 & \multirow[t]{3}{*}{57.51} & \multirow[t]{3}{*}{$91.68 \pm 0.5$} & \\
\hline & 0.442 & 57.11 & & & \\
\hline & 0.441 & 58.02 & & & \\
\hline \multirow[t]{3}{*}{250} & 0.340 & 75.68 & \multirow[t]{3}{*}{76.46} & \multirow[t]{3}{*}{$97.58 \pm 0.6$} & \multirow[t]{3}{*}{35.04} \\
\hline & 0.341 & 76.36 & & & \\
\hline & 0.338 & 77.34 & & & \\
\hline \multirow[t]{3}{*}{500} & 0.226 & 89.88 & \multirow[t]{3}{*}{89.96} & \multirow[t]{3}{*}{$102.69 \pm 0.5$} & \\
\hline & 0.221 & 90.26 & & & \\
\hline & 0.222 & 89.11 & & & \\
\hline \multirow[t]{3}{*}{1000} & 0.174 & 99.79 & \multirow[t]{3}{*}{100.29} & \multirow[t]{3}{*}{$106.51 \pm 0.5$} & \\
\hline & 0.175 & 100.09 & & & \\
\hline & 0.177 & 101.07 & & & \\
\hline
\end{tabular}

Table 6: Spectroscopic Determination of Anti-inflammatory Activity of Standard Compound (Diclofenac- Na)

\begin{tabular}{|l|l|}
\hline Test Sample & IC50 \\
\hline Leaves & 944.06 \\
\hline Standard & 35.04 \\
\hline
\end{tabular}

Table 7: Comparative study based on IC50

In this research work, it exposed that the plant extracts might have moderate anti-inflammatory effect which is possibly reconciled by HRBC membrane stabilization.

\section{Antioxidant activity}

Here, the free radical-scavenging action of extracts was assessed with the DPPH assay [11]. In this research work, it exposed that the plant extracts may have important antioxidant effect which is may be reconciled by inhibition of DPPH free radical, which is accountable for oxidation.

\begin{tabular}{|l|l|l|}
\hline & Absorbance & Average \\
\hline & 0.813 & \\
\hline Control & 0.817 & 0.819 \\
\hline & 0.829 & \\
\hline
\end{tabular}

Table 8: Average absorbance of control

\begin{tabular}{|c|c|c|c|c|c|}
\hline Concentration $(\mu \mathrm{g} / \mathrm{ml})$ & Absorbance & $\% \mathrm{SCV}$ & Average & $\% \mathrm{SCV} \pm \mathrm{SEM}$ & IC50 $(\mu \mathrm{g} / \mathrm{ml})$ \\
\hline \multirow[t]{3}{*}{62.5} & 0.863 & 21.68 & \multirow[t]{3}{*}{21.91} & \multirow[t]{3}{*}{$9.79 \pm 0.6$} & \\
\hline & 0.857 & 22.00 & & & \\
\hline & 0.852 & 22.07 & & & \\
\hline \multirow[t]{3}{*}{125} & 0.557 & 36.91 & \multirow[t]{3}{*}{36.89} & \multirow[t]{3}{*}{$33.03 \pm 0.5$} & \\
\hline & 0.551 & 36.69 & & & \\
\hline & 0.552 & 37.05 & & & \\
\hline \multirow[t]{3}{*}{250} & 0.415 & 63.98 & \multirow[t]{3}{*}{63.99} & \multirow[t]{3}{*}{$63.99 \pm 0.6$} & \multirow[t]{3}{*}{594.47} \\
\hline & 0.410 & 64.87 & & & \\
\hline & 0.411 & 63.06 & & & \\
\hline \multirow[t]{3}{*}{500} & 0.214 & 79.61 & \multirow[t]{3}{*}{79.08} & \multirow[t]{3}{*}{$79.08 \pm 0.7$} & \\
\hline & 0.210 & 78.20 & & & \\
\hline & 0.211 & 79.39 & & & \\
\hline \multirow[t]{3}{*}{1000} & 0.115 & 99.98 & \multirow[t]{3}{*}{100.53} & \multirow[t]{3}{*}{$100.50 \pm 07$} & \\
\hline & 0.088 & 100.90 & & & \\
\hline & 0.088 & 100.67 & & & \\
\hline \multirow[t]{3}{*}{2000} & 0.075 & 108.57 & \multirow[t]{3}{*}{108.7} & \multirow[t]{3}{*}{$108.7 \pm 0.6$} & \\
\hline & 0.079 & 107.99 & & & \\
\hline & 0.077 & 109.17 & & & \\
\hline
\end{tabular}

Table 9: Spectroscopic Determination of Antioxidant Activity of Leaves. 


\begin{tabular}{|c|c|c|c|c|c|}
\hline Concentration $(\mu \mathrm{g} / \mathrm{ml})$ & Absorbance & $\% \mathrm{SCV}$ & Average & $\% \mathrm{SCV} \pm \mathrm{SEM}$ & $\operatorname{IC50}(\mu \mathrm{g} / \mathrm{ml})$ \\
\hline \multirow[t]{3}{*}{62.5} & 0.451 & 71.54 & \multirow[t]{3}{*}{71.87} & \multirow[t]{3}{*}{$71.87 \pm 0.5$} & \\
\hline & 0.452 & 71.50 & & & \\
\hline & 0.450 & 72.57 & & & \\
\hline \multirow[t]{3}{*}{125} & 0.361 & 81.38 & \multirow[t]{3}{*}{80.80} & \multirow[t]{3}{*}{$80.80 \pm 0.37$} & \\
\hline & 0.369 & 80.13 & & & \\
\hline & 0.368 & 80.90 & & & \\
\hline \multirow[t]{3}{*}{250} & 0.297 & 88.28 & \multirow[t]{3}{*}{88.88} & \multirow[t]{3}{*}{$88.88 \pm 0.51$} & \multirow[t]{3}{*}{106.38} \\
\hline & 0.289 & 89.85 & & & \\
\hline & 0.297 & 88.53 & & & \\
\hline \multirow[t]{3}{*}{500} & 0.099 & 96.79 & \multirow[t]{3}{*}{97.28} & \multirow[t]{3}{*}{$97.28 \pm 0.31$} & \\
\hline & 0.097 & 97.40 & & & \\
\hline & 0.096 & 97.66 & & & \\
\hline \multirow[t]{3}{*}{1000} & 0.077 & 104.61 & \multirow[t]{3}{*}{104.50} & \multirow[t]{3}{*}{$104.50 \pm 0.3$} & \\
\hline & 0.056 & 104.29 & & & \\
\hline & 0.035 & 104.60 & & & \\
\hline \multirow[t]{3}{*}{2000} & 0.033 & 107.66 & \multirow[t]{3}{*}{106.93} & \multirow[t]{3}{*}{$106.93 \pm 0.7$} & \\
\hline & 0.030 & 107.25 & & & \\
\hline & 0.029 & 105.90 & & & \\
\hline
\end{tabular}

Table 10: Spectroscopic Determination of Antioxidant Activity of Standard Compound (L- Ascorbic Acid)

\begin{tabular}{|l|l|}
\hline Test Sample & IC $_{50}$ \\
\hline Leaves & 594.47 \\
\hline Standard & 106.38 \\
\hline
\end{tabular}

Table 11: Comparative study based on $\mathrm{IC}_{50}$

In this research work, it exposed that the plant extracts may have important antioxidant effect which is might be reconciled by the inhibition of the DPPH free radical.

\section{Conclusion}

By this research study it was concluded that the qualitative estimations indicate substantial existence of saponins, flavonoids, phenols, terpenoids and also triterpenes. In the plant, this was also concluded that glycosides, alkaloids and also tannins are moderately present. The quantitative assessments demonstrate substantial presence of phenols than tannin. There is an outstanding antioxidant activity in methanolic extract oh this plant. There was also reasonable anti-inflammatory activity in methanolic extract of this plant's leaves. So each part of the Elettaria cardamomum has altered constituent and the pharmacological properties of this plant vary in relation to part of the plant evaluated. Here the $\mathrm{IC}_{50}$ values by the DPPH scavenging observed for the standard and the leaves were $106.38 \mu \mathrm{g} / \mathrm{ml}$ and $594.47 \mu \mathrm{g} / \mathrm{ml}$ separately. Consequently, there is a wonderful antioxidant activity in methanolic extract of this plant. Furthermore, there was also reasonable anti-inflammatory activity in methanolic extract of this plant's leaves. So, it is assessed that the $\mathrm{IC}_{50}$ values for the anti-inflammatory action by the standard and the plant leaves were $35.04 \mu \mathrm{g} / \mathrm{ml}$ and $944.06 \mu \mathrm{g} / \mathrm{ml}$ separately.

\section{References}

1. Meyer S. (1982) phytochemical methods a guide to modern techniques of plant analysis. USA: Champan and Hall.

2. Korikanthimathm VS, Prasath D, Rao G. (2001) Medicinal properties of cardamom Ellettaria cardamomum. J Med Aroma plant sci. 22/4A \& 23/ 1A, 683-685.

3. AZWANIDA, N. (2015). A review on the extraction methods use in medicinal plants, principle, strength and limitation. Med Aromat Plants, 4, 2167-0412.1000196.

4. Kaushik P, Goyal P, Chauhan A, Chauhan G. (2015) In vitro evaluation of antibacterial potential of dry fruit extract of Ellatria cardamom Maton (chhoti elaichi). Iranian J Pharma Res. 9 (3), 287-297.

5. PORSOLT, R., BERTIN, A. \& JALFRE, M. (1977a). Behavioral despair in mice: a primary screening test for antidepressants. Archives internationales de pharmacodynamie et de therapie, 229, 327-336

6. Jazila EM, Mountassif D, Amarouch H. (2007) Antimicrobial activity of Elettaria cardamomum: Toxicity, biochemical and histological studies. Food Chemistry 104, 1560-1568.

7. Jamal A, Javed K, Aslam M, Jafri M.A. (2006) Gastroprotective effect of cardamom, Elettaria cardamomum Maton fruits in rats . J Ethnopharmacol 103, 149-153.

8. Verma S.K, Jain V, Katewa S.S. (2009) Blood pressure lowering fibrinolysis enhancing and antioxidant activities of cardamom (Ellatria cardamom). Indian J Biochem biophysics 46, 503-506.

9. Gilani A.H, Jabeen Q, Khan A.U, Shah A.J. (2008) Gut modulatory, Blood pressure lowering, Duretic and Sedative activities of cardamom. J Ethnopharmacol 115, 463-472.

10. WU, W. \& SUN, R. (2012). Toxicological studies on plant proteins: a review. Journal of Applied Toxicology, 32, 377-386.

11. Alam MA, Ghani A, Subhan N, Rahman M, Haque MS, Majumder MM, Majumder MEH, Akter RA, Nahar L, Sarkar SD (2008). Antioxidant and membrane stabilizing properties of the flowering tops of Anthocephalus cadamba. Nat. Prod. Commun. 3:65-67.

12. Dubey A, Nayak S, Goupale DC (2011). A review on phytochemical, pharmacological and toxicological studies on Neolamarckia cadamba. Der. Pharm. Let. 3:45-54. 